\title{
Strategic alliances: an analysis of Catalan hospitals
}

\author{
Merce Bernardo, ${ }^{1}$ Jaume Valls, ${ }^{1}$ and Marti Casadesus ${ }^{2}$
}

Suggested citation

Bernardo M, Valls J, Casadesus M. Strategic alliances: an analysis of Catalan hospitals. Rev Panam Salud Publica. 2012;31(1):40-7.

ABSTRACT Objective. To analyze the strategic alliances that Catalan hospitals form with other health care entities and other types of institutions to foster technological and organizational innovation.

Methods. Qualitative case studies were conducted at a sample of 16 public hospitals in Catalonia, Spain. The sample was limited to three (Level 1-3) of Catalonia's four levels of hospitals (classified according to the complexity of the diagnoses and treatments they provide), but Level 4 hospitals were considered as part of the network in the analysis of the alliances. At each hospital, interviews were conducted with the manager, the medical director, and the service director, using a questionnaire that gathered information on strategic alliances with a focus on telemedicine. Qualitative data processing was applied to identify patterns of alliances between hospitals and other institutions.

Results. Catalan hospitals interact with other health care agents through three main types of associations: alliances with other hospitals (the most frequent type); alliances with primary care centers (reported mostly by Level 2 hospitals); and alliances with other institutions (e.g., local government, medical companies, and universities). Human resource-sharing (staff mobility) and training were reported most frequently as reasons for creating the alliances.

Conclusions. Strategic alliances are formed between hospitals and other health care agents to help improve performance, competitiveness, and services provided to users. These results may help health care system managers promote strategic alliances as a means of optimizing system efficiency without reducing user satisfaction - a key challenge within the context of the current economic situation.

Key words Organizational innovation; economics, hospital; hospital shared services; strategic planning; Spain.

As the demand for good-quality health care increases worldwide, developed countries have gradually increased the proportion of gross domestic product (GDP) invested in improving their health care systems. The average

\footnotetext{
1 Departament d'Economia i Organitzacio d'Empreses, Universitat de Barcelona, Barcelona, Spain. Send correspondence to: Merce Bernardo, merce.bernardo@ub.edu

2 Departament d'Organitzacio, Gestio Empresarial i Disseny de Producte, Universitat de Girona, Girona, Spain.
}

health expenditure as a share of GDP was $9.0 \%$ in 2008 among Organization of Economic Co-Operation and Development (OECD) countries, with the biggest spenders being the United States $(16.0 \%)$, France $(11.2 \%)$, and Switzerland $(10.7 \%)$, and the lowest Mexico $(5.9 \%)$ and Turkey (6.0\%) (1). Health sector spending in OECD countries is largely financed through public funding, except for the United States and Mexico, where private funding accounts for over $50.0 \%$ of total health expenditure (1).
In many countries, increasing pressures on health systems and slow growth in health expenditures (1) have produced a situation in which health care providers must increase their efficiency in order to continue providing satisfactory levels of health care without sacrificing user satisfaction (2). To achieve this objective, various changes in structure and organization are required. In both of these aspects, innovation can help to increase value and efficiency. Innovation may include technological 
advances $(3,4)$ as well as new strategies, organizational structures, facilities, processes, and partnerships (2, 5-9). Although technological and organizational innovation is interrelated, it is the latter that provides an institution with the greatest opportunities to gain a competitive advantage (2).

Whether or not a hospital achieves this competitive advantage depends on its ability to adapt quickly to changes in health care policies (10). Like other types of institutions, hospitals tend to innovate as needed to maintain desired levels of performance, competitiveness, and service provision but may not have the requisite resources to do so on their own (11). Some of the resources required for innovation may be controlled by outside organizations within the local (or extended) environment (12). Hospitals' relationships with these organizations can thus be crucial in terms of their market survival. According to Tidd et al. (13), organizations may collaborate with other [outside] entities in order to 1 ) reduce the cost and risk of technological development or market entry; 2) achieve scale economies in production; 3 ) reduce the time taken to develop and commercialize new products; and 4) promote shared learning. The collaboration may take various forms, including licensing agreements, strategic alliances, joint ventures, and networking.

Strategic alliances aim to achieve competitive advantages for their partners (14). According to Novotny et al. (15), a strategic alliance is a partnership between two firms that are engaged in similar or complementary activities and decide to pool their resources to achieve a common goal. Strategic alliances are also defined as any formal arrangement between two or more organizations for the purposes of ongoing cooperation and mutual gain-risk sharing (16). In health care, a strategic alliance, whether formal or informal, can be defined as two or more hospitals pooling resources to achieve a long-term objective that is beyond the reach of a single hospital (13, 17-19).

According to Doz and Hamel (20), strategic alliances and strategies are formed to 1) build critical mass through co-option, 2) reach new markets by leveraging co-specialized resources, and 3) gain new competencies through organizational learning, and advantages are created by reducing the cost of service provision and diversifying risk. According to other research, alliances also 1) allow for greater specialization of network institutions, 2) promote knowledge creation and transfer, and 3) increase the diversity of services that are offered (providing a better product or service quality) as well as benefits (21, 22). Collaboration is easier when partners' organizational structure, mission, and purpose are similar (16). The success of strategic alliances depends on two factors: the relationship between the partners, and partnership performance $(15,17)$.

In the case of hospitals, strategic alliances can be set up with other institutions to promote collaboration between specific departments or units with regard to information and communication technologies or the sharing of medical information or health care professionals' services. For example, alliances may involve the use of telemedicine to help hospitals exchange information $(23,24)$ in order to improve the service, diagnoses, and treatment provided to hospital users. The main advantages of telemedicine for both patients and providers (25-29) are summarized in Table 1.

TABLE 1. Telemedicine alliances: applications and potential benefits for health care providers and users, based on research for strategic hospital alliance study, Catalonia, Spain, 2006-2007

\begin{tabular}{|c|c|c|}
\hline \multirow[b]{2}{*}{ Applications } & \multicolumn{2}{|c|}{ Potential benefits } \\
\hline & All health care providers & Health care providers in remote areas \\
\hline $\begin{array}{l}\text { Sharing of medical } \\
\text { information }\end{array}$ & $\begin{array}{l}\text { Improves patient diagnoses } \\
\text { (working collaboratively, a group } \\
\text { of health care professionals } \\
\text { can share knowledge about a } \\
\text { diagnosis, thus enriching their } \\
\text { overall knowledge of certain } \\
\text { specialty areas) }\end{array}$ & $\begin{array}{l}\text { Reduce gaps in service due to a lack } \\
\text { of specialists (often an issue for health } \\
\text { care facilities located in remote regions) }\end{array}$ \\
\hline \multirow[t]{3}{*}{$\begin{array}{l}\text { Sharing of health care } \\
\text { professionals' services } \\
\text { across different locations/ } \\
\text { entities }\end{array}$} & $\begin{array}{l}\text { Improves users' level of } \\
\text { satisfaction by facilitating and } \\
\text { increasing access to an expanded } \\
\text { array of health care services, and } \\
\text { eliminating the need to travel to } \\
\text { other (more specialized) health } \\
\text { care facilities for certain diagnoses } \\
\text { and treatments }\end{array}$ & \\
\hline & $\begin{array}{l}\text { Improves the patient-doctor } \\
\text { relationship }\end{array}$ & \\
\hline & Increases organizational efficiency & \\
\hline $\begin{array}{l}\text { Training of health care } \\
\text { professionals }\end{array}$ & $\begin{array}{l}\text { Facilitates training process and } \\
\text { cuts costs; allows professionals } \\
\text { from one health care entity } \\
\text { to share knowledge with } \\
\text { professionals at another entity }\end{array}$ & \\
\hline
\end{tabular}

a Data based mainly on references 25-29.
This article analyzes the strategic alliances created between hospitals and outside health care facilities and other institutions to promote organizational innovation.

\section{MATERIALS AND METHODS}

This descriptive qualitative empirical research was based on case studies of a sample of 16 hospitals in the Catalan region in northeastern Spain.

\section{Catalan health care system}

Spain's health care system has two main characteristics: 1) universal coverage (i.e., all citizens receive care for free), and 2) since 1981, decentralized control (i.e., each autonomous region within Spain manages its own health care system). Due to this decentralization the health care system may differ across regions (30).

According to OECD data, health expenditure as a share of GDP in Spain was $9.0 \%$ in 2008 , with $6.5 \%$ corresponding to public health spending and $2.5 \%$ to the private sector.

Prior to decentralization, users' health coverage in Catalonia was based on a
of health care professionals' services across different locations/ entities
Training of health care professionals 
mutual insurance system. This tradition has influenced the design of the present health care system, particularly as regards the financial model. Like the rest of Spain, Catalonia has both public and private hospitals. However, the Catalan health care system has a unique feature: thanks to an agreement between the public and private networks, when users from the public network need medical care that is only available from private health facilities, the patient receives the treatment at the private hospital and the regional government covers the costs (31).

Another characteristic of the system is the way hospitals are classified. Apart from public versus private, hospitals are grouped according to the level of complexity of the diagnoses and treatments they provide. There are four types of hospitals in the system (32):

- Level 1: small or geographically isolated hospitals in which few specialties are treated;

- Level 2: basic, general hospitals that cover the usual health requirements of the population;

- Level 3: reference hospitals in which practically all health problems can be treated;

- Level 4: high-technology hospitals that treat specific illnesses requiring the use of specialized equipment/ procedures.

\section{Methodology}

Sixteen case studies were conducted to trace the evolution of hospitals' performance over time in order to evaluate the potential benefits of strategic alliances. A descriptive and mainly exploratory methodology was used. As explained in two studies by Eisenhardt and Yin (33, $34)$, respectively, this type of research aims to identify general propositions regarding the practices observed. This type of methodology has also been reported to be well suited for analyzing the complex process of adoption and internalization of organizational innovations and their impact on hospital performance (35).

The current study is part of a broader project ("Innovation in Catalan hospitals: best practices") analyzing innovations implemented in Catalan hospitals in the public regional network. This is reflected in the questionnaire design (which was revised by a former hospital manager) and the choice of interviewees (defined by the Catalan government). The project fieldwork had three main components. The first stage comprised in-depth, semistructured interviews with the hospital manager, medical director, and service director (or equivalent). The interviews, which lasted an average of one hour, were sufficiently open as to be consistent with the inductive method of data analysis that was used without distorting the data collection process. The objective of the interviews was to obtain interviewees' narratives rather than specific answers (34). The second stage was a face-to-face visit to the hospitals under study. The third stage included review of internal documents provided by some of the hospitals on various institutional innovations (strategic plans, the creation of special staff teams, etc.). Internal validity was guaranteed by the search for common patterns underlying the phenomena under study. Reliability was ensured by the use of structured interviews with the same order and number of questions, and a protocol assessing cases against each factor.

For the project as a whole, a total of 50 case studies (overseen by the Catalan government) were carried out. Hospital interviews and visits were conducted by pairs of trained research team members. None of the interviews were recorded. Notes were taken by both researchers and then cross-contrasted, as per recommendations in the literature (34). The grounded theory method recommended for use in case studies in operations management research (36) was used for the comparisons. All interviews were coded a posteriori in order to define categories to aid interpretation of the findings. ATLAS.ti version 5.0 (Scientific Software Development, Berlin, Germany) was applied to facilitate the structuring of information and the encoding process.

In the project questionnaire (which was used for all 50 case studies), interviewees were asked to describe any technical, organizational, or service innovations implemented by their hospital over the last three years (or planned for the future) that they considered important. Other innovations that may have been implemented but were not mentioned by the informants were not considered in the study. In addition to the questionnaire (which included a set of open questions), survey respondents completed a checklist. The set of open questions were grouped by type of innovation (technological versus organizational).

Questions about technological innovation focused on advancements in diagnoses (e.g., digital radiology) and treatments (e.g., anticoagulant and nuclear medicine) as well as general areas such as medical and surgery specialties. Questions about organizational innovation covered the hospital's use of alliances (strategic associations with other health care entities or other types of institutions); special information systems (e.g., electronic medical records); telemedicine (e.g., the exchange of images with other health care facilities); and process reengineering (e.g., the reorganization of the emergency unit or merging of two similar units).

\section{The current study}

The sample for the current study comprised 16 case studies from the Catalan public regional hospital network that summarized the main technological and organizational innovations that had been implemented (or planned for the future) by each of the 16 hospitals. Limiting the sample in this way avoided the risk of recording redundant information (37). Three hospitals were Level 1, nine were Level 2, and four were Level 3. Due to the difficulty of comparing hightechnology (Level 4) hospitals with the other types of hospitals (Levels 1-3), no Level 4 hospitals were included in the sample.

The results presented here are based on the interviewees' responses to questions about technological and organizational innovation. The information obtained in the responses to these questions was relatively limited because innovation was not the only aspect analyzed in the project. As a result, some interesting aspects of alliances were not explored, such as the transaction costs that they represent for hospitals, and the main barriers faced in the relationships.

\section{RESULTS}

The data obtained in the study about strategic associations within the Catalan hospital network are presented in two different ways: by type of hospital (level of complexity of diagnoses and treatments), and type of alliance. 


\section{Type of hospital}

Level 1. Level 1 hospitals tend to be small facilities near the international border with a small number of patients. Their main challenges are a high volume of patient transfers (i.e., the need to move patients to Level 3 or Level 4 facilities to receive specialized services and treatments that Level 1 hospitals do not provide), and a lack of professional staff.

The main solution to the first challenge has been to form an alliance with other hospitals (including those outside the network) that can provide more specialized services. As one Level 1 hospital manager explained, "Alliances may be formed with other hospitals to ensure that patients do not have to be transferred a long distance." One Level 1 hospital described its collaboration with French hospitals that enabled it to send a patient over the border to France for emergency services rather than to a Level 3 or Level 4 Catalan hospital $200 \mathrm{~km}$ away.

Survey respondents from Level 1 hospitals also mentioned the difficulty in contracting professional staff, which they attributed to their remote locations and job candidates' perceptions that employment with Level 1 institutions did not offer the opportunity to develop a broad range of expertise. Many cited telemedicine as a promising solution to the lack of onsite professional staff.

Although Level 1 survey respondents agreed that alliances could help their institutions become more competitive, hospitals at this level had the lowest level of partnerships.

Level 2. Level 2 hospitals are basic, general hospitals that form alliances with various entities throughout the health care system, especially primary care centers. Their main priorities are 1) improving management, 2) building up their professional staff, and 3) strengthening their relationship with other types of institutions (e.g., local government, medical/pharmaceutical companies, and universities).

Level 2 hospitals serve a large population and often collaborate with other institutions in various areas such as the procurement of medical devices or the adoption of information systems. Staff mobility is a common feature of Level 2 hospitals, allowing both institutions and primary care physicians to benefit from the knowledge of experts from higherlevel hospitals. For example, one Level 2 hospital reported sharing its head of emergency services with a Level 3 hospital. According to the survey respondent, this arrangement allows for "great human resource flexibility and good relationships with patients."

Evidence of the relationship between Level 2 hospitals and their local community was borne out in survey respondents' reports of various collaborations with local government (e.g., the provision of help and advice on water system maintenance by Level 2 hospital staff) and retirement homes (the provision of in-house care and treatment by Level 2 hospital staff, eliminating the need for the residents to travel to a hospital).

One Level 2 hospital administrator stressed the importance of telemedicine alliances and explained that telecare was only possible as a result of the hospital's well-developed information system. Other survey respondents from Level 2 hospitals expressed an interest in providing the same type of service.

Level 3. Level 3 or reference hospitals provide services to other health care facilities, especially Level 2 hospitals. These hospitals have a high level of staff mobility and the alliances they form often involve research and training.

FIGURE 1. Examples of alliances between primary care centers and different types of hospitals (Levels 1-4), based on 16 qualitative case studies, Catalonia, Spain, 2006-2007

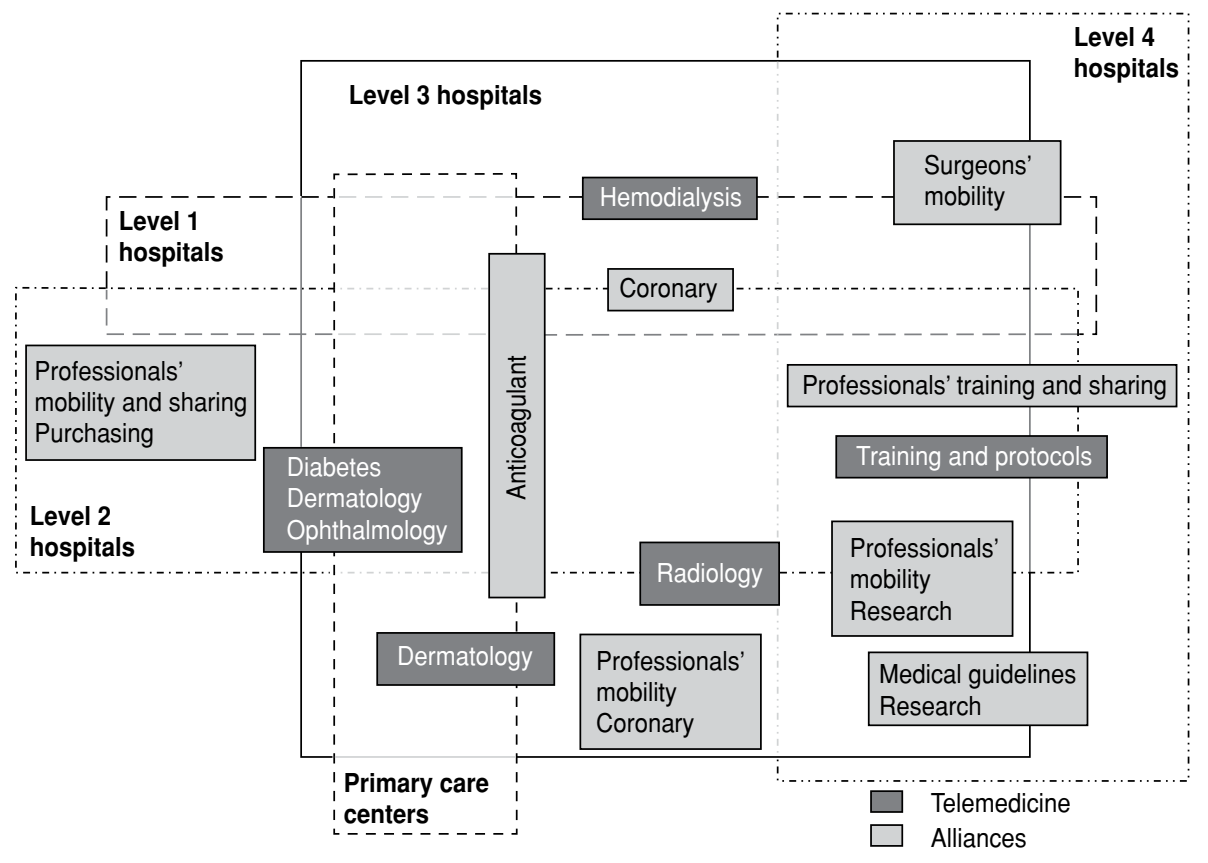

Staff mobility and the human resource-sharing that it enables is important because of the insufficient number of specialists in the Catalan health care system. In addition, working in different environments may provide useful experience for the staff members themselves. The high degree of staff mobility at Level 3 hospitals also allows for their collaboration with health care partners and other types of institutions in research and training.

\section{Type of alliance}

Survey respondents from the 16 hospitals that were studied reported involvement in a total of 91 alliances. The level of formality of these alliances was not explicitly defined. Three main types of collaboration were cited: 1) alliances with other hospitals, 2) alliances with primary care centers, and 3) alliances with other types of institutions (e.g., local government, medical companies, and universities). Figure 1 shows examples of alliances between hospitals and primary care centers reported in the study. The three types of alliances are described below.

1. Alliances between hospitals. This is the most common type of alliance in the Catalan health system, accounting for $71.4 \%$ (65 alliances). These partnerships 
TABLE 2. Characteristics of strategic alliances within the Catalan hospital network, by type of hospital and alliance, based on 16 qualitative case studies, Catalonia, Spain, 2006-2007

\begin{tabular}{|c|c|}
\hline Type of hospitala & Type of alliance(s) and main characteristics \\
\hline \multicolumn{2}{|l|}{ Level 1 and ... } \\
\hline Level 2 & Alliances that mainly involve coronary treatment \\
\hline Level 3 & $\begin{array}{l}\text { Alliances between different units (e.g., radiology and endocrinology) that often allow } \\
\text { Level } 1 \text { hospital surgeons to operate on patients at Level } 3 \text { hospitals. As one medical } \\
\text { director explained, this is desirable because "patients are more satisfied if their doctor } \\
\text { is present during the operation." Level } 1 \text { and Level } 3 \text { hospitals also form hemodialysis } \\
\text { alliances using telemedicine (the most frequently reported type of alliance for Level } 1 \\
\text { hospitals). }\end{array}$ \\
\hline Level 4 & $\begin{array}{l}\text { Alliances that mainly involve training and sharing of health care professionals' services } \\
\text { (staff mobility). Like the alliances with Level } 3 \text { hospitals, these alliances often include } \\
\text { agreements that allow Level } 1 \text { surgeons to be present at their patients' operations. }\end{array}$ \\
\hline \multicolumn{2}{|l|}{ Level 2 and ... } \\
\hline Level 2 & $\begin{array}{l}\text { Alliances focused on cooperation and shared human resources. For example, two } \\
\text { of the Level } 2 \text { hospitals surveyed have the same head of emergency services. At } \\
\text { another pair of Level } 2 \text { hospitals, the same specialists see patients in several units. } \\
\text { A main characteristic of these alliances is staff mobility. Level } 2 \text { hospitals also form } \\
\text { management alliances (in which administrators from Level } 2 \text { hospitals in the same } \\
\text { zone or subregion collaborate by sharing resources, purchasing shared medical } \\
\text { devices, adopting the same information system, etc.); training alliances; and research } \\
\text { alliances (e.g., the development and production of medical guidelines). Some of these } \\
\text { alliances may involve telemedicine. }\end{array}$ \\
\hline Level 3 & $\begin{array}{l}\text { Common alliances that include the sharing of human resources and management tool } \\
\text { applications. Training is not a main focus of these alliances, but staff from the different } \\
\text { partner institutions may collaborate on research projects. These associations may also } \\
\text { include telemedicine alliances in which Level } 2 \text { hospitals send radiology images to } \\
\text { Level } 3 \text { hospitals for evaluation by their specialists. }\end{array}$ \\
\hline Level 4 & $\begin{array}{l}\text { Alliances that focus on training, either in person or via telemedicine. Human resources } \\
\text { (health care professionals and hospital management) are also shared between these } \\
\text { two types of hospitals. Alliances between units may also exist in specialized areas } \\
\text { (e.g., oncology, pediatrics, and AIDS). }\end{array}$ \\
\hline \multicolumn{2}{|l|}{ Level 3 and ... } \\
\hline Level 3 & $\begin{array}{l}\text { Alliances that involve the use of telemedicine (for radiology) and staff mobility (which } \\
\text { may benefit health care professionals' careers by providing them with broader work } \\
\text { experience) }\end{array}$ \\
\hline Level 4 & $\begin{array}{l}\text { Alliances that mainly involve research (e.g., studies on lung capacity or mental } \\
\text { disorders, and development / production of medical guidelines) }\end{array}$ \\
\hline
\end{tabular}

are grouped by hospital level and described in detail in Table 2. Although Level 4 hospitals were not specifically studied (for reasons explained above) they are included in the table with respect to 1) alliances mentioned by survey respondents from other types of hospitals, and 2) their role in the hospital network.

\section{Alliances between hospitals and pri-} mary care centers. This is the second most common type of alliance, comprising $16.5 \%$ or 15 alliances:

- Level 1 hospitals. Primary care centers and Level 1 hospitals collaborate in anticoagulant treatment, with the primary care doctor controlling the treatment (Figure 1), and pharmacy. This is the weakest association found in the sample.
- Level 2 hospitals. Alliances between Level 2 hospitals and primary care centers are the most common type of alliance. They can be classified into three main categories: telemedicine, specialists' support, and treatments.

In telemedicine alliances (Figure 1), primary care center physicians send diabetes, coronary disease, and ophthalmology images to the appropriate specialist at the Level 2 hospital for diagnosis. This means that patients do not have to go to the hospital. Telemedicine is also applied in dermatology services when primary care doctors have doubts about their diagnoses.

The support provided to primary care centers by Level 2 hospital specialists takes two different forms. In the first, the Level 2 specialist sees the patient at the primary care center.
In the second, the specialist helps the primary care doctor resolve any questions about patient diagnoses.

The main services provided by Level 2 specialists at primary care centers are anticoagulant treatment (Figure 1) and nursery care.

- Level 3. Like primary care alliances with Level 2 hospitals, primary care alliances with specialists at Level 3 hospitals are focused on support of primary care doctors. Specialists from these hospitals also provide anticoagulant treatment and use telemedicine to share images of dermatology diseases (Figure 1).

3. Alliances between hospitals and other types of institutions. Ten alliances (10.9\% of all alliances reported in the study) were between hospitals and other 
types of institutions, including local government, medical companies, and universities:

- Level 1 hospitals. Because many Level 1 hospitals are located in remote areas and lack the ability to provide certain services, they often enter into agreements to receive complementary medical services from private health care providers, such as weekly radiology and magnetic resonance services, and ophthalmology support.

- Level 2 hospitals. The main type of alliance between Level 2 hospitals and other institutions occurs with local government in areas of public health. In these types of alliances, hospital staff may provide advice on proper maintenance of infrastructure (e.g., water systems) as well as specialized services (e.g., rehabilitation and traumatology). Alliances with universities are based on research and training. Two of the 16 hospitals studied also have agreements with retirement homes.

- Level 3 hospitals. Level 3 hospitals reported training alliances with universities, care and treatment alliances with retirement homes, and collaborative research alliances with universities. One hospital conducts joint research with local government. Collaboration with a private company for the provision of traumatology services using telemedicine was also reported.

\section{DISCUSSION}

The aim of this study was to analyze the strategic alliances created between hospitals, other health care facilities, and other types of institutions to foster technological and organizational innovation. The qualitative cases studies carried out at the 16 hospitals map existing alliances within the Catalan hospital network and assess their effect on the institutions' performance, competitiveness, and the services they provide to users.

The results reveal three main types of interactions: 1) alliances between hospitals, 2) alliances between hospitals and primary care centers, and 3) alliances between hospitals and other types of institutions (local government, medical companies, and universities). These types of interactions can be informal (38) and may evolve due to geographical proximity (39).
Hospitals collaborate most with other hospitals and primary care centers. Hospital alliances reduce hospitalization costs and increase benefits for patients $(40,41)$. Collaboration with primary care centers is based on the same idea (decentralizing certain treatments to reduce the need for users to travel to other facilities in the network to receive specialized services). In some of the interactions, especially those between hospitals, similarities in terms of institution type or level and organizational structure has also made the collaboration easier $(12,15)$.

According to the results of the current study, the main reasons for creating alliances are human resource-sharing (staff mobility) and training. Sharing of human resources was the most frequently cited solution for insufficient staffing at certain institutions across the network. Staff training involved both hospitals and primary care centers and was provided either via telemedicine or in person. Telemedicine usually involved the exchange of images $(24,42)$, and in isolated areas it was highlighted as an important alliance component by interviewees from Level 1 hospitals, although not to the same degree as staff mobility. These results differed from those from a study by Amarenco and Nadjar (26) that indicated the most important reason for forming telemedicine alliances in remote regions was to reduce the need for patient travel between different hospitals. The current survey results also indicated one of the critical tasks facing Level 1 hospitals is determining how to best develop telecare (12).

Although the general conclusion among survey respondents was that alliances are positive and should be promoted, certain difficulties were mentioned with regard to their implementation, such as some managers' fear of losing health care professionals to other institutions as a result of human resource-sharing, increased management costs, and the lack of sufficient governmental support.

Based on the results of the study, managers of health care systems should consider at least two cross-functional variables in determining how to increase efficiency: information systems and human resources. Information systems are crucial in the implementation of telemedicine and telecare because distance communication relies on them. Human resources are crucial in telemedicine, and strategic alliances overall, because without the involvement and motivation of the people who make up the organization their implementation is unlikely to be a success $(35,43)$.

\section{Limitations}

This study has two main limitations. The first involves a special characteristic of the sample (the Catalan hospital network): In the Catalan health care system, private hospitals may provide services to public network users. This feature makes the system more competitive and increases users' satisfaction. Without the complementary support of private institutions, the public system would not be able to provide many of its current services and overall health provision would be weaker. However, this characteristic also means that the results of the current study cannot be extrapolated directly to other regions in Spain, because the number of specialized services offered by hospitals in the region examined in the study sample may be higher. Evidence of this is the increasing number of patients from health care systems in other regions who receive treatment in Catalonia. The second study limitation is the point of view of the interviewees, as all alliances reported in the current results were described and evaluated by the hospital management and thus exclude the viewpoint of other staff members.

\section{Conclusion and future research directions}

The current findings could inform implementation of strategic alliances by hospital and network managers seeking to improve network efficiency and user satisfaction. For hospital managers, the most important effects of strategic alliances are the increase in knowledge among health care professionals and the reduction of costs. These results may help health care system managers promote these types of relationships as a means of increasing efficiency without sacrificing user satisfaction, a key objective in health care system management, particularly within the context of the current economic climate.

In their future research on strategic alliances among health care institutions, the authors plan to apply social network analysis in a sample of high-technology (Level 4) hospitals to study the relationship between the types of alliances that 
are formed and the information systems that are available at each hospital.

Acknowledgments. The authors would like to thank the hospital managers and research team. The study was made possible by the "Innovation in Catalan Hospitals" research contract (2006-2007) awarded by the Department of Health of the Regional Government of Catal- onia (Generalitat de Catalunya, GENCAT). The authors would also like to thank two anonymous reviewers for their comments on previous versions of this article.

\section{REFERENCES}

1. Organisation for Economic Co-operation and Development [home page on the Internet]. Paris: OECD; 2011. Available from: http:// www.oecd.org. Accessed 20 April 2011.

2. Porter ME, Teisberg EO. Redefining health care: creating value-based competition on results. Boston: Harvard Business School Press; 2006.

3. Hammer M, Champy J. Reengineering the corporation: a manifesto for business revolution. New York: Harper Business; 1993.

4. Dosi G. Innovation, organization and economic dynamics: selected essays. Cheltenham, UK: Edward Elgar Publishing; 2000.

5. Porter ME. Competitive advantage: creating and sustaining superior performance. New York: The Free Press; 1985.

6. Andreasen LE, Coriat B, den Hertog F, Kaplinsky R, editors. Europe's next step: organizational innovation, competition and employment. London: Frank Cass; 1995.

7. Howells J. The management of innovation \& technology. London: Sage; 2005.

8. Organisation for Economic Co-operation and Development. Oslo Manual: guidelines for collecting and interpreting innovation data. 3rd ed. Paris: OECD; 2005.

9. Birkinshaw J, Hamel G, Mol MJ. Management innovation. Acad Manage Rev. 2008; 33(4):825-45.

10. Otte A, Dierckx RA, Otte K. The hospital organization of the future. Nucl Med Rev Cent East Eur. 2004;7(2):103-5.

11. Boex JR, Henry RC. Principles to guide AHC-community partnerships. Acad Med. 2001;76(2):151-2.

12. Jones $\mathrm{N}$, Thomas P. Inter-organizational collaboration and partnerships in health and social care. The role of social software. Public Policy Admin. 2007;22(3):289-302.

13. Tidd J, Bessant J, Pavitt K. Managing innovation: integrating technological, market and organizational change. 3rd ed. Chichester, UK: John Wiley \& Sons; 2005.

14. Das TK, Teng BS. A resource-based theory of strategic alliances. J Manage. 2000;26(1): 31-61.

15. Novotny JM, Donahue M, Bhalla BB. The clinical partnership as strategic alliance. J Prof Nurs. 2004;20(4):216-21.

16. Zajac EJ, D'Aunno TA, Burns LR. Managing strategic alliances. In: Shortell SM, Kaluzny $\mathrm{AD}$, editors. Health care management: organization, design, and behavior. 5th ed. Clifton Park, NY: Thomson Delmar Learning; 2006.

17. Chatman VS, Buford JF, Plant B. The building and sustaining of a health care partnership: the Meharry-Vanderbilt Alliance. Acad Med. 2003;78(11):1105-13.
18. Burns LR, Lee JA. Hospital purchasing alliances: utilization, services, and performance. Health Care Manage Rev. 2008;33(3):203-15.

19. Miles PV, Miller M, Payne DM, Perelman R, Saffer M, Zimmerman E; Alliance for Pediatric Quality. Alliance for pediatric quality: creating a community of practice to improve health care for America's children. Pediatrics. 2009;123 Suppl 2:S64-6.

20. Doz YL, Hamel G. Alliance advantage: the art of creating value through partnering. Boston: Harvard Business Press; 1998.

21. Cowan R, Jonard N, Zimmermann JB. Bilateral collaboration and the emergence of innovation networks. Manage Sci. 2007;53(7):105167.

22. Salge TO, Vera A. Hospital innovativeness and organizational performance: evidence from English public acute care. Health Care Manage Rev. 2009;34(1):54-67.

23. Deluca JM, Enmark R. E-health: the changing model of healthcare. Front Health Serv Manage. 2000;17(1):3-15.

24. Menachemi N, Burke DE, Ayers DJ. Factors affecting the adoption of telemedicine-a multiple adopter perspective. J Med Syst. 2004;28(6):617-32.

25. Whitten $P$, Love B. Patient and provider satisfaction with the use of telemedicine: overview and rationale for cautious enthusiasm. J Postgrad Med. 2005;51(4):294-300.

26. Amarenco P, Nadjar M. Telemedicine for improving emergent management of acute cerebrovascular syndromes. Int J Stroke. 2007;2(1):47-50.

27. Bar-Sela SM, Glovinsky Y. A feasibility study of an Internet-based telemedicine system for consultation in an ophthalmic emergency room. J Telemed Telecare. 2007;13(3):119-24.

28. Trief $P$, Teresi J, Izquierdo $R$, Morin $P$, Goland $\mathrm{R}$, Field L, et al. Psychosocial outcomes of telemedicine case management for elderly patients with diabetes: the randomized IDEATel trial. Diabetes Care. 2007;30(5):1266-8.

29. Duplantie J, Gagnon MP, Fortin JP, Landry R. Telehealth and the recruitment and retention of physicians in rural and remote regions: a Delphi study. Can J Rural Med. 2007;12(1):30-6.

30. Ministerio de Sanidad y Consumo, Sistema Nacional de Salud (ES). Informe annual Sistema Nacional de Salud 2004. Madrid: MSC; 2006. Available from: http://www.msc. es/organizacion/sns/informeAnualSNS/ informe2004.htm Accessed 15 May 2006.

31. Generalitat de Catalunya. El Departament de Salut-balanç i perspectives: "Salut a prop." Barcelona: GENCAT; 2006. Available from: http://www.gencat.cat/salut/ depsalut/pdf/bal06.pdf Accessed 15 May 2006.
32. Generalitat de Catalunya. Memòria d'activitats. Barcelona: GENCAT; 1999. Available from: http://www10.gencat.net/catsalut/ archivos/publicacions/memories/1999/ scs99/HTML/principal.html Accessed 10 February 2007.

33. Eisenhardt KM. Building theories from case study research. Acad Manage Rev. 1989;14(4):532-50.

34. Yin RK. Case study research: design and methods. Thousand Oaks, CA: Sage; 2009.

35. Carruthers J, Ashill NJ, Rod M. Mapping and assessing the key management issues influencing UK public healthcare purchaserprovider cooperation. Qual Market Res Int J. 2006;9(1):86-102.

36. Binder M, Edwards JS. Using grounded theory method for theory building in operations management research: a study on inter-firm relationship governance. Int J Oper Prod Man. 2010;30(3):232-59.

37. Maxwell JA. Qualitative research design: an interactive approach. Thousand Oaks, CA: Sage; 1996.

38. Sarradon-Eck A, Vega A, Faure M, HumbertGaudart A, Lustman M. Linking: relationships between health professionals in the informal health networks [article in French]. Rev Epidemiol Sante Publique. 2008;56 Suppl 3:S197-206

39. Asheim BT, Gertler M. The geography of innovation: regional innovations systems. In: Fagerberg J, Mowery D, Nelson R, editors. The Oxford Handbook of Innovation. Oxford: Oxford University Press; 2005. Pp. 56-85.

40. Bielaszka-DuVernay C. Taking public health approaches to care in Massachusetts. Health Aff (Millwood). 2011;30(3):435-8.

41. Harris M. A new paradigm slashes hospital use and nursing home stays for the elderly and the physically and mentally disabled. Health Aff (Millwood). 2011;30(3):412-5.

42. Bernardo M, Valls J, Aparicio P. Organisational innovations in Catalan hospitals: the case of telemedicine. Int J Healthcare Technology and Management. 2011;12(3/4): 307-20.

43. Gagnon MP, Lamothe L, Fortin JP, Cloutier A, Godin G, Gagné C, et al. Telehealth adoption in hospitals: an organisational perspective. J Health Organ Manag. 2005;19(1):32-56.

Manuscript received on 27 October 2010. Revised version accepted for publication on 14 June 2011. 
RESUMEN Objetivo. Analizar las alianzas estratégicas que los hospitales catalanes forjan con otras entidades de atención de la salud y otros tipos de instituciones para fomentar la innovación tecnológica y de las organizaciones.

Alianzas estratégicas: un análisis de los hospitales catalanes

Métodos. Se condujeron estudios cualitativos de casos en una muestra de 16 hospitales públicos de Cataluña, España. La muestra se limitó a tres (Niveles 1 a 3) de los cuatro niveles de los hospitales catalanes (clasificados según la complejidad de los diagnósticos y los tratamientos que proporcionan), pero los hospitales de Nivel 4 se consideraron parte de la red en el análisis de las alianzas. En cada hospital se efectuaron entrevistas con el gerente, el director médico y el director de servicio, mediante un cuestionario que recopilaba información sobre las alianzas estratégicas con hincapié en la telemedicina. Se aplicó el procesamiento cualitativo de datos para identificar los modelos de alianzas entre los hospitales y otras instituciones.

Resultados. Los hospitales catalanes interactúan con otros agentes de atención de la salud a través de tres tipos principales de asociaciones: alianzas con otros hospitales (el tipo más frecuente); alianzas con centros de atención primaria (según lo informado principalmente por los hospitales de Nivel 2); y alianzas con otras instituciones (por ejemplo, el gobierno local, las empresas médicas y las universidades). El intercambio de recursos humanos (movilidad del personal) y la capacitación fueron mencionados como los motivos más frecuentes para crear las alianzas.

Conclusiones. Se forman alianzas estratégicas entre los hospitales y otros agentes de atención de la salud con el objeto de mejorar el desempeño, la competitividad y los servicios prestados a los usuarios. Estos resultados pueden ayudar a los gerentes de los sistemas de atención de la salud a promover alianzas estratégicas como medio para optimizar la eficiencia del sistema sin reducir la satisfacción de los usuarios —un reto clave en el contexto de la situación económica actual.

Palabras clave Innovación organizacional; economía hospitalaria; servicios hospitalarios compartidos; planificación estratégica; España. 